\title{
Penerapan ISO 9126 Dalam Pengujian Kualitas Perangkat Lunak pada E-book
}

\author{
Supriyono, Vika Anindya K, Nurchaerani Kadir, Jihan Febriana,Eka Puji Rahayu, Hagar Prily T
}

\begin{abstract}
The increase in the use of e-books in education is growing rapidly. Along with the development of information technology there is no standard measurement to measure the quality of a software product in the development of e-Book. In this study focused on breakthrough technological development on the quality evaluation of the SOFTWARE PRODUCT. As such, this paper presents a study to test the quality of the software by implementing the ISO 9126 standard, especially the external quality model of the E-Book. There are five models to determine the quality of a software namely Boehm, FURPS, McCall, Dromey and ISO-9126. The implementation of ISO 9126 in E-Book resulted in the identification of five quality characteristics namely functionality, reliability, usability, efficiency, and portability. Of these five characteristics result in sixteen sub characteristics among others suitability, accurateness, ecurity, interoperability, maturity, fault-tolerance, coverability, understandability, learnability, operability, attractiveness, Time behavior, adaptability, installability, coexistence, replaceability. There are two contributions of this paper, namely the software quality Model for e-Book; and identification of quality metrics to support the evaluation of software PRODUCT xproducts. The results of implementing ISO 9126 models are used to test the quality of the software products in e-books and software quality metrics.
\end{abstract}

Index Terms- E-Book, ISO 9126, software.

Abstrak-- Peningkatan penggunaan e-Book dalam dunia pendidikan semakin berkembang cukup pesat. Seiring dengan perkembangan teknologi informasi belum ada standart pengukuran untuk mengukur kualitas suatu produk perangkat lunak dalam pengembangan e-Book. Pada penelitian ini fokus pada terobosan pengembangan teknologi pada evaluasi kualitas produk perangkat lunak. Dengan demikian, paper ini menyajikan studi untuk menguji kualitas perangkat lunak dengan menerapkan standar ISO 9126, khususnya model kualitas eksternal pada e-Book. Terdapat lima model untuk menentukan kualitas dari suatu software yaitu Boehm, FURPS, McCall, Dromey dan ISO-9126. Penerapan ISO 9126 pada e-Book menghasilkan identifikasi lima karakteristik kualitas yaitu functionality, reliability, usability , efficiency,

Supriyono, Teknik Informatika, Universitas Islam Negeri Maulana Malik Ibrahim, Malang, Indonesia; (email priyono@ti.uinmalang.ac.id)

Vika Anindya K, Nurchaerani Kadir, Jihan Febriana, Eka Puji Rahayu, Hagar Prily T, Teknik Informatika, Universitas Islam Negeri Maulana Malik Ibrahim, Malang, Indonesia; dan portability. Dari lima karakteristik tersebut menghasilkan enam belas sub karakteristik antara lain suitability, accurateness, security, interoperability, maturity, fault-tolerance, recoverability, understandability, learnability, operability, attractiveness, time behavior, adaptability, installability, coexistence, replaceability. Ada dua kontribusi dari paper ini, yaitu Model Kualitas Perangkat Lunak untuk e-Book; dan identifikasi metrik kualitas untuk mendukung evaluasi xproduk perangkat lunak. Hasil penerapan model ISO 9126 digunakan untuk menguji kualitas produk perangkat lunak dalam e-Book dan metrik kualitas perangkat lunak.

\section{Kata Kunci- E-book, ISO 9126, Perangkat Lunak.}

\section{Pendahuluan}

$\mathrm{P}$ erkembangan teknologi informasi khususnya di bidang teknologi informatika telah berkembang dan menyentuh seluruh aspek kehidupan. Salah satunya di bidang penerbitan, yaitu mengubah dari buku tradisional menjadi buku digital electronic book. Adanya kemajuan ini bermanfaat untuk meningkatkan aktivitas membaca dengan menyediakan medium portable dan fleksibel serta memberi peluang kepada siapa saja yang dapat memiliki suatu perpustakaan digital tanpa biaya.

Beberapa studi mengakui pentingnya e-book sebagai alat untuk memfasilitasi pengajaran dan pembelajaran[1]. Sebagai alat, e-Book menghasilkan efek positif pada kinerja siswa dan produktivitas guru [2]. Tujuannya adalah untuk mendukung kegiatan belajar dan mengekspos siswa pada Teknologi Informasi dan Komunikasi (TIK). Spesifikasi dan evaluasi produk perangkat lunak yang komprehensif adalah faktor kunci dalam memastikan kualitas yang dapat dicapai dengan mendefinisikan karakteristik kualitas yang tepat, dengan mempertimbangkan tujuan dari produk perangkat lunak. Karakteristik perangkat lunak yang tepat dapat meningkatkan kolaborasi antar pemrogram dan antar organisasi bisnis, yang memungkinkan suatu fungsi digunakan oleh aplikasi lain tanpa perlu mengetahui detail pemrograman yang terdapat di dalamnya [3]. Karakteristik kualitas yang relevan ditentukan dan dievaluasi menggunakan metrik yang divalidasi dan / atau diterima [4]. Untuk mengevaluasi kualitas produk akhir, diperlukan seperangkat karakteristik kualitas yang menjelaskan produk tersebut. ISO-9126 merupakan standart pengukuran jaminan kualitas perangkat lunak. Ide 
dasarnya adalah menentukan dan mengevaluasi produk perangkat lunak untuk mengetahui internal quality dan external quality. Dengan demikian, paper ini bertujuan untuk menerapkan model ISO 9126 yang merupakan standar ISO untuk menguji kualitas produk perangkat lunak pada e-Book.

\section{TINJAUAN PUSTAKA}

Perkembangan perangkat lunak mengalami peningkatan yang cukup pesat. Termasuk perkembangan e-book yang saat ini dengan gencar dikembangkan dengan berbagaim macam platform pengembangan. Dengan menggunakan analisa dan perancangan pengambangan sistem serta rekayasa kebutuhan dapat menghasilkan perangkat lunak yang handal dan tepat guna [5]. Seperti pada e-book terdapat beberapa fitur pengembangan yang bertujuan memudahkan pengguna. Sebagai contoh sistem e-book yang memungkinkan pembaca berhenti di halaman tertentu dan memperbesar area teks tertentu [6]. E Book awal termasuk Dynabook dan Data Discman sebelum kemajuan dalam ilmu komputer menyaksikan munculnya Amazon Kindle, Barnes dan Noble Nook, Apple-iPad dan e-Book pada Google. E-Books modern adalah representasi komputer dari buku fisik. Konten dapat sesederhana halaman yang dipindai ke yang lebih 'hidup', dengan penggabungan animasi dan suara.

Model kualitas perangkat lunak dapat digambarkan sebagai seperangkat karakteristik dan hubungan di antara mereka, yang memberikan dasar untuk menentukan persyaratan kualitas dan mengevaluasi kualitas produk [7]. ISO 9126 didasarkan pada model sebelumnya lebih lengkap dan mencakup hampir semua karakteristik kritis termasuk struktur, kriteria evaluasi, dan hubungan [8].

ISO-9126 merupakan standard pengukuran jaminan kualitas perangkat lunak. Ide dasarnya adalah menentukan dan mengevaluasi produk perangkat lunak untuk mengetahui kualitas internal dan kualitas eksternal serta hubungannya dengan atribut kualitas [8]. Untuk memberikan kerangka kerja kualitas perangkat lunak, Organisasi Internasional untuk Standardisasi (ISO) dan Komisi Teknis Elektro Internasional (IEC) telah mengembangkan standar ISO 9126 untuk rekayasa Perangkat Lunak. Kualitas produk, untuk menyediakan spesifikasi dan model evaluasi yang komprehensif untuk kualitas produk perangkat lunak. Kualitas dianggap sebagai salah satu driver paling penting dari keberhasilan perangkat lunak. Selama tiga dekade terakhir [9].

Dalam ISO 9126, totalitas atribut kualitas diklasifikasikan ke dalam struktur hierarki karakteristik pohon dan sub-karakteristik. Ini menetapkan enam karakteristik: Fungsi, Keandalan, Kegunaan, Efisiensi, Maintabilitas dan Portabilitas. Keuntungan utama dari ISO 9126 adalah karakteristiknya berlaku untuk setiap jenis perangkat lunak sambil memberikan terminologi yang konsisten [10]. Ini juga mencakup karakteristik kritis seperti struktur hierarkis; kriteria evaluasi; dan definisi sederhana.
ISO 9126 tidak menentukan persyaratan kualitas spesifik untuk produk perangkat lunak, tetapi menjelaskan model kualitas, yang dapat diterapkan ke perangkat lunak apa pun. Standar ini mencakup pandangan pengguna dan memperkenalkan konsep Quality in Use [11]. Kualitas perangkat lunak saat beroperasi di lingkungannya seperti yang dilihat oleh pengguna daripada sifat-sifat perangkat lunak itu sendiri. Kepuasan pengguna sering digunakan untuk menentukan keberhasilan perangkat lunak. Implementasi program aplikasi tidak terlepas dengan adanya proses manajemen yang bagus[12]. Perangkat lunak yang sesuai dengan identifikasi kebutuhan merupakan tolok ukur keberhasilan dalam meningkatkan kualitas produk perrangkat lunak yang dihasilkan.

\section{PEMBAHASAN}

Hasil dari proses analisis pada lima karakteristik kualitas eksternal seperti fungsionalitas (fungsionality), keandalan (reliability), kegunaan (usability), efisiensi (efficiency) dan portabilitas (portability). Generalitas ISO 9126 diperlukan analisis serta pemetaan lebih lanjut sebelum sepenuhnya dapat diadaptasi ke e-Book. Karena tidak ada karakteristik yang dapat diukur secara langsung, dan harus dinilai dalam hal tujuan seta kriteria e-Book.

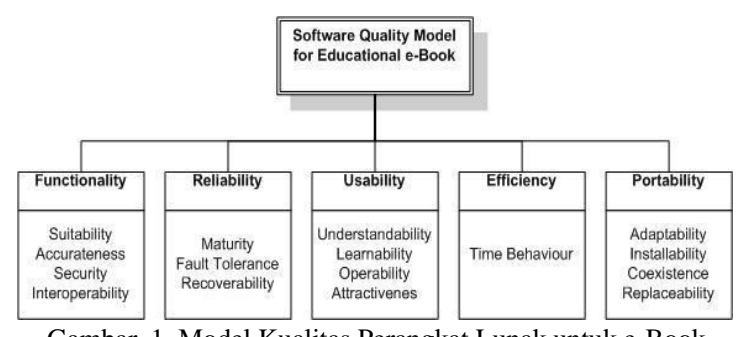

Gambar. 1. Model Kualitas Perangkat Lunak untuk e-Book

Karakteristik Fungsionalitas, Keandalan, Kegunaan, Efisiensi, dan Portabilitas dipilih karena sangat bergantung pada domain aplikasi tempat e-Book dimiliki. Fungsionalitas dipilih karena tergantung pada domain aplikasi, dan Keandalan menyangkut penyajian informasi serta konten dalam produk akademik. Kegunaan dimasukkan karena mengacu pada kemampuan produk perangkat lunak untuk menyediakan fungsi yang bisa digunakan dalam mencapai tujuannya.

Maintainability dikecualikan karena biasanya dievaluasi oleh pengembang atau vendor pihak ketiga dengan akses ke kode sumber. Meskipun sebagian besar produk perangkat lunak menganggap Maintainability sebagai karakteristik kualitas yang penting, itu hanya dievaluasi pada tahap awal pengembangan. Hal ini sesuai dengan evaluasi produk perangkat lunak dalam domain akademik, karena Maintainability dan Portability tidak dilihat sebagai karakteristik yang signifikan. Namun, Portabilitas termasuk dalam pekerjaan ini karena produk perangkat lunak perlu ada bersama dengan yang sudah ada. Model yang diterapkan 
untuk e-Book diilustrasikan pada Gambar.1, daftar karakteristik dan sub-karakteristik berdasarkan pada model ISO 9126.

Fungsionalitas adalah "kemampuan dalam perangkat lunak digunakan untuk penyediaan fungsi-fungsi yang memenuhi kebutuhan user dengan dinyatakan atau tersirat". Karakteristik ini dapat dievaluasi melalui fungsi dan layanan yang diberikan kepada pengguna. Ini termasuk persyaratan untuk metafora buku dasar, alat navigasi, dan mesin pencari. Sub-karakteristik yang sesuai untuk e-book adalah Kesesuaian, Keakuratan, Keamanan dan Interoperabilitas. Tabel 1 memberikan metrik kualitas untuk Fungsionalitas dan subkarakteristiknya.

Tabel 1. Functionality Quality Metrics.

\begin{tabular}{|c|c|}
\hline Sub - Characteristics & Quality Metrics \\
\hline \begin{tabular}{lrr}
\multicolumn{3}{c}{ Suitability } \\
Bisakah perangkat & lunak \\
melakukan $\quad$ tugas & yang \\
dibutuhkan? & &
\end{tabular} & $\begin{array}{l}\text { The extent to which e-Book : } \\
\text { Menyediakan serangkaian fungsi } \\
\text { dan tujuan yang tepat seperti } \\
\text { metafora buku dasar, fungsi } \\
\text { elektronik, dan objek fisik. }\end{array}$ \\
\hline \begin{tabular}{l}
\multicolumn{3}{c}{ Accurateness } \\
Bisakah perangkat lunak \\
menghasilkan hasil yang \\
diharapkan?
\end{tabular} & $\begin{array}{l}\text { The extent to which e-Book: } \\
\text { Memberikan hasil yang diharapkan } \\
\text { atau efek untuk tugas dan tujuan } \\
\text { yang ditentukan seperti alat } \\
\text { navigasi, mesin pencari dan } \\
\text { referensi silang. }\end{array}$ \\
\hline 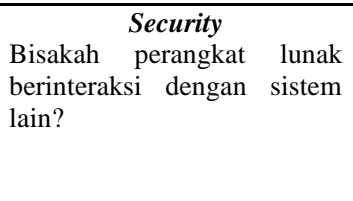 & $\begin{array}{l}\text { Security measures in e-Book: } \\
\text { Menjaga kerahasiaan informasi } \\
\text { termasuk otentikasi, prosedur } \\
\text { login, tampilan data sensitif, } \\
\text { perlindungan kata sandi, dan hak } \\
\text { istimewa pengguna }\end{array}$ \\
\hline $\begin{array}{l}\text { Interoperability } \\
\text { Apakah perangkat lunak } \\
\text { dilengkapi dengan tindakan } \\
\text { pengamanan? }\end{array}$ & $\begin{array}{l}\text { The extent to which e-Book: } \\
\text { Batasi akses dari perangkat lunak } \\
\text { lain dan sediakan konten ke } \\
\text { perpustakaan digital. }\end{array}$ \\
\hline
\end{tabular}

\section{- Reliability}

Reliabilitas merupakan kemampuan suatu produk perangkat lunak (software) dalam mempertahankan tingkat kinerjanya pada kondisi tertentu yang telah ditetapkan pada periode waktu yang ditentukan.

Tabel 2: Reliability Quality Metrics.

\begin{tabular}{|c|l|}
\hline \multicolumn{1}{|c|}{ Sub - Characteristics } & \multicolumn{1}{|c|}{ Quality Metrics } \\
\hline $\begin{array}{l}\text { Maturity } \\
\text { Bisakah sebagian besar } \\
\text { kesalahan dihilangkan dari } \\
\text { waktu ke waktu? }\end{array}$ & $\begin{array}{l}\text { Reliability of } \text {-Book: } \\
\text { Dalam hal frekuensi kegagalan } \\
\text { perangkat lunak dan fungsi bebas } \\
\text { kesalahan. }\end{array}$ \\
\hline $\begin{array}{l}\text { Fault Tolerance } \\
\text { Bisakah perangkat lunak } \\
\text { menangani kesalahan? }\end{array}$ & $\begin{array}{l}\text { Fault tolerance of } \boldsymbol{e} \text {-Book: } \\
\text { Menangapi input yang tidak valid } \\
\text { mempertahankan kinerja jika terjadi } \\
\text { kesalahan perangkat lunak. }\end{array}$ \\
\hline
\end{tabular}

\begin{tabular}{|c|c|}
\hline Sub - Characteristics & Quality Metrics \\
\hline Recoverability & Recoverability of e-Book: \\
\hline $\begin{array}{l}\text { Apakah perangkat lunak } \\
\text { dapat bekerja dan } \\
\text { mengembalikan data? }\end{array}$ & $\begin{array}{l}\text { Segera melanjutkan pekerjaan } \\
\text { setelah kegagalan, cepat pulih dari } \\
\text { kegagalan dan memperingatkan } \\
\text { pengguna untuk mengambil tindakan } \\
\text { setelah kesalahan dikenali. }\end{array}$ \\
\hline
\end{tabular}

\section{- Usability}

Kegunaan adalah seperangkat atribut yang mengukur persepsi utilitas sistem dan kepuasan untuk seperangkat pengguna yang dinyatakan atau yang tersirat. Kegunaan dalam E-Book melibatkan Understandability (mampu dipahami), Learnability (mampu dipelajari), Operability (mampu dioperasikan) dan Attractiveness (menarik) sebagai sub karakteristiknya. Pada tabel 3 menunjukkan kegunaan quality metrics.

Tabel 3: Usability (Kegunaan) Quality Metrics.

\begin{tabular}{|c|c|}
\hline Sub - Characteristics & Quality Metrics \\
\hline \begin{tabular}{l}
\multicolumn{1}{c}{ Understandability } \\
Bisakah perangkat lunak \\
dipahami dengan \\
mudah?
\end{tabular} & $\begin{array}{l}\text { The capability of e-Book in providing: } \\
\text { Tombol berfungsi dengan baik, tata } \\
\text { letak / template yang konsisten, } \\
\text { penggunaan istilah yang konsisten, } \\
\text { penentuan posisi yang konsisten dari } \\
\text { pesan kesalahan, tugas antarmuka yang } \\
\text { konsisten, yang dapat dengan mudah } \\
\text { dipahami, dan cukup jelas tentang isi } \\
\text { dan tombol. }\end{array}$ \\
\hline \begin{tabular}{l}
\multicolumn{1}{c}{ Learnability } \\
Bisakah perangkat lunak \\
dipelajari dengan \\
mudah?
\end{tabular} & $\begin{array}{l}\text { Learnability of e-Book with regards to: } \\
\text { Belajar menggunakan perangkat lunak, } \\
\text { mengeksplorasi fitur atau fungsi baru } \\
\text { dengan coba-coba, penggunaan } \\
\text { perintah, alat navigasi dan alat } \\
\text { pencarian, dan melakukan tugas, } \\
\text { penggunaan daftar isi, penggunaan } \\
\text { pesan bantuan online dan kejelasan } \\
\text { instruksi. }\end{array}$ \\
\hline \begin{tabular}{l}
\multicolumn{1}{c}{ Operability } \\
Bisakah perangkat lunak \\
dioperasikan dengan \\
upaya minimal?
\end{tabular} & $\begin{array}{l}\text { Operating e-Book: } \\
\text { Dalam menemukan informasi yang } \\
\text { diperlukan (seperti menggunakan } \\
\text { daftar isi), organisasi informasi, urutan } \\
\text { layar, dan melakukan tugas (seperti } \\
\text { pencarian informasi, penggunaan alat } \\
\text { navigasi, dll). }\end{array}$ \\
\hline $\begin{array}{l}\text { Attractiveness } \\
\text { Apakah perangkat lunak } \\
\text { memiliki antarmuka } \\
\text { yang menarik? }\end{array}$ & $\begin{array}{l}\text { Attractiveness of e-Book: } \\
\text { Dari sudut antarmuka pengguna, } \\
\text { template dan multimedia dalam } \\
\text { produk perangkat lunak. }\end{array}$ \\
\hline
\end{tabular}

\section{- Efficiency}

Efisiensi adalah "kemampuan software dalam pemberian kinerja yang tepat, relatif pada jumlah sumber daya yang digunakan". Efisiensi adalah konsep kompleks yang menawarkan tantangan konseptual maupun kesulitan implementasi. Ini merujuk pada seberapa baik e-Book memenuhi tujuannya. Time Behavior adalah satu-satunya sub-karakteristik untuk 
Efisiensi dalam e-Book. Tabel 4 merupakan ilustrasi dari efisiensi.

Tabel 4: Efficiency (efisiensi) Quality Metrics

\begin{tabular}{|c|c|}
\hline Sub - Characteristics & Quality Metrics \\
\hline $\begin{array}{l}\text { Time behavior } \\
\text { Apakah perangkat lunak } \\
\text { berperilaku tepat waktu? }\end{array}$ & $\begin{array}{l}\text { The capability of e-Book to: } \\
\text { Menyediakan waktu respons } \\
\text { yang sesuai (dari fungsi } \\
\text { bantuan / alat navigasi, } \\
\text { fungsi pencarian, tombol } \\
\text { berikutnya dan sebelumnya), } \\
\text { menyediakan } \\
\text { pemrosesan yang sesuai } \\
\text { (waktu pemuatan), } \\
\text { menangani dokumen besar, } \\
\text { mencari operasi dan } \\
\text { informasi dengan cepat, } \\
\text { melakukan urutan operasi } \\
\text { dengan ekonomi gerak } \\
\text { (jumlah klik mouse untuk } \\
\text { mendapatkan r halaman } \\
\text { berikutnya). }\end{array}$ \\
\hline
\end{tabular}

\section{- Portability}

Portabilitas adalah "kemampuan produk software yang dapat dikirim dari satu lingkup ke lingkup lain". Produk perangkat lunak dalam e-Book harus dengan mudah ditransfer ke lingkungan lain jika diperlukan (teknologi baru, dll). Sub-karakteristik yang sesuai meliputi Kemampuan Beradaptasi, Kemampuan Berinstalasi, Koeksistensi dan Kemampuan Berganti yang ditunjukkan pada tabel 5. Bagian ini telah membahas dan mengusulkan penyempurnaan model ISO 9126 untuk e-Book. Model yang disempurnakan menyediakan metode formal untuk mengevaluasi kualitas produk perangkat lunak dalam e-Book. Metrik kualitas pada Tabel 2-6 dapat berfungsi sebagai dasar untuk pengembangan instrumen survei dan sistem dukungan komputer untuk eBook.

Tabel 5: Portability (Portabilitas) Quality Metrics

\begin{tabular}{|c|c|}
\hline Sub - Characteristics & \multicolumn{1}{|c|}{ Quality Metrics } \\
\hline $\begin{array}{c}\text { Adaptability } \\
\text { disakah perangkat lunak }\end{array}$ & $\begin{array}{l}\text { Ability of e-Book in terms of: } \\
\text { Beradaptasi dengan berbagai } \\
\text { perangkat keras atau platform } \\
\text { OS tanpa upaya tambahan. }\end{array}$ \\
\hline $\begin{array}{c}\text { Installability } \\
\text { diinstal dengan mudah? }\end{array}$ & $\begin{array}{l}\text { Ability of e-Book in terms of: } \\
\text { Upaya yang diperlukan untuk } \\
\text { menginstal produk perangkat } \\
\text { lunak di lingkungan yang } \\
\text { ditentukan selain platform awal. }\end{array}$ \\
$\begin{array}{c}\text { Coexistence } \\
\text { bekerja dengan sistem } \\
\text { perangkat lunak yang ada? }\end{array}$ & $\begin{array}{l}\text { Ability of e-Book in terms of: } \\
\text { Tingkat kesesuaian produk } \\
\text { dengan standar atau konvensi } \\
\text { yang terkait dengan } \\
\text { portabilitas. }\end{array}$ \\
\hline \multicolumn{2}{|c}{ dingangat } \\
\hline
\end{tabular}

\begin{tabular}{|c|l|}
\hline Sub - Characteristics & \multicolumn{1}{|c|}{ Quality Metrics } \\
\hline Replaceability & $\begin{array}{l}\text { Ability of e-Book in terms of: } \\
\text { Peluang dan upaya untuk } \\
\text { digakah perangkat lunak dengan produk } \\
\text { serupa? }\end{array}$ \\
& $\begin{array}{l}\text { perangkanakan lunak sebagai } \\
\text { pengganti aplikasi lain atau } \\
\text { perangkat lunak yang lebih } \\
\text { lama. }\end{array}$ \\
\hline
\end{tabular}

\section{KESIMPULAN}

Paper ini telah menghasilkan studi tentang penggunaan standar kualitas perangkat lunak ISO 9126, terutama model Kualitas Eksternal, Upaya penelitian terutama berfokus pada terobosan teknologi dan perhatian terbatas telah diberikan pada evaluasi kualitas produk perangkat lunak. Dengan demikian, paper ini menyajikan studi untuk menguji kualitas perangkat lunak dengan menerapkan standar ISO 9126, khususnya model kualitas eksternal pada e-Book. Terdapat lima model untuk menentukan kualitas dari suatu software yaitu Boehm, FURPS, McCall, Dromey dan ISO-9126. Penelitix menghasilkan identifikasi lima karakteristikx kualitas (Functionality, Reliability,x Usability, Efficiency, Portability). Tujuannya adalah untuk untuk menguji kualitas xproduk xperangkat lunak dalam eBook dan metrik kualitas yang berfungsi sebagai tolak ukur untuk pengembangan instrumen survei dan sistem pendukung komputer. Dalam proses ini, functionality untuk mengambil e-book ke dalam konteks, karakteristik ini dapat dievaluasi melalui fungsi dan layanan yang diberikan kepada pengguna. Usability guna pada e-Book yang melibatkan xUnderstandability, Learnability, Operability, dan Attractiveness sebagai sub-karakteristiknya. Effisiency merujuk pada seberapa baik e-Book memenuhi tujuannya. Portability membuat Produk perangkat lunak dalam e-Book harus dengan mudah ditransfer ke lingkungan lain jika diperlukan atau menggunakan teknologi baru, dan teknologi yang lainnya.

\section{REFERENCES}

[1] Yager, S. E., \& Szabo, Z. 2011. Using an e-book to teach technology. Proceedings of the 49th SIGMIS Annual Conference on Computer Personnel Research - SIGMIS-CPR '11.

[2] Roslina , W., Fahmy , S., Fariha, Z., Haslinda ,N., Yacob, A., Sukinah , N., Suhana , N. 2013. The Effect of e-Book on Students' Learning Styles A Study in Terengganu, Malaysia. Proceedings of the 2013 International Conference on Advanced ICT

[3] Supriyono. 2015. Integrasi Web Services Dengan Menggabungkan Perancangan Berorientasi Objek dan SOA Untuk Membangun Sistem e-Learning. MATICS, 7(1), p.31.

[4] Landoni, M. 2010. Evaluating e-books. Proceedings of the third workshop on Research advances in large digital book repositories and complementary media - BooksOnline ' 10 .

[5] Supriyono, \& Muslimah, E. 2018. Perancangan Sistem Informasi Manajemen Kas Berbasis Web Studi Kasus: RS dr. Etty Asharto Batu. MATICS, 10(1), p.21.

[6] Haslinda N., Fariha M. A. Z., Fahmy A. W. S., Roslina W. O. W., Sukinah A. A. N., Azliza Y., Suhana S. N., Nurshuhada S. 2014. Refinement of the ISO 9126 Model for Evaluating Software Product Quality in e-Book, Malaysia. 
[7] Al-Qutaish, R.E. 2009. An Investigation of the Weaknesses of the ISO 9126 International Standard. 2009 Second International Conference on Computer and Electrical Engineering.

[8] Bazzana, G., Andersen, O. \& Jokela, T., ISO 9126 and ISO 9000: friends or foes? Proceedings 1993 Software Engineering Standards Symposium.

[9] Behkamal, B., Kahani, M. \& Akbari, M.K. 2009. Customizing ISO 9126 quality model for evaluation of B2B applications. Information and Software Technology, 51(3), pp.599-609.
[10] Idri A. \& Abran A. 2013. Tentang Penggunaan Standar Kualitas Perangkat Lunak ISO / IEC9126 di Lingkungan Bergerak. AsiaPacific Software Engineering Conference.

[11] Stefani, A. \& Xenos, M. 2007. E-commerce system quality assessment using a model based on ISO 9126 and Belief Networks. Software Quality Journal, 16(1), pp.107-129.

[12] Supriyono, S. 2016. Rancang Bangun Sistem Informasi Penjualan dengan Menerapkan Metode Akuntansi Persediaan Rata-rata. MATICS, 7(2), p.77. 